\title{
A ddRADseq Survey of the Genetic Diversity of Rye (Secale cereale L.) Landraces from the Western Alps Reveals the Progressive Reduction of the Local Gene Pool
}

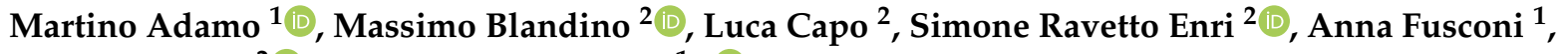 \\ Michele Lonati $^{2}$ (D) and Marco Mucciarelli ${ }^{1, *}$ (D) \\ 1 Dipartimento di Scienze della Vita e Biologia dei Sistemi (DBIOS), Università degli Studi di Torino, \\ Viale P.A. Mattioli 25, 10125 Torino, Italy; martino.adamo@unito.it (M.A.); anna.fusconi@unito.it (A.F.) \\ 2 Dipartimento di Scienze Agrarie, Forestali e Alimentari (DISAFA), Università degli Studi di Torino, \\ Largo Paolo Braccini 2, 10095 Grugliasco, Italy; massimo.blandino@unito.it (M.B.); luca.capo@unito.it (L.C.); \\ simone.ravettoenri@unito.it (S.R.E.); michele.lonati@unito.it (M.L.) \\ * Correspondence: marco.mucciarelli@unito.it
}

Citation: Adamo, M.; Blandino, M.; Capo, L.; Ravetto Enri, S.; Fusconi, A.; Lonati, M.; Mucciarelli, M. A ddRADseq Survey of the Genetic Diversity of Rye (Secale cereale L.) Landraces from the Western Alps Reveals the Progressive Reduction of the Local Gene Pool. Plants 2021, 10, 2415. https://doi.org/10.3390/ plants10112415

Academic Editor:

Ioannis Ganopoulos

Received: 15 September 2021

Accepted: 4 November 2021

Published: 9 November 2021

Publisher's Note: MDPI stays neutral with regard to jurisdictional claims in published maps and institutional affiliations.

Copyright: (c) 2021 by the authors. Licensee MDPI, Basel, Switzerland. This article is an open access article distributed under the terms and conditions of the Creative Commons Attribution (CC BY) license (https:/ / creativecommons.org/licenses/by/ $4.0 /)$.

\begin{abstract}
Rye (Secale cereale L.) has been at the basis of agriculture for centuries in most mountainous and northern areas of Eurasia, because it is more resistant than other cereals to low temperatures and poor soils. Rye deserves to be re-evaluated as a source of "environmentally resilient" genes in the future as well, and particularly in a perspective to grow cereals able to withstand global warming. According to recent studies, modern rye varieties have a relatively narrow genetic pool, a condition that is worsening in the most recent breeding processes. The preservation of local landraces as unique sources of genetic diversity has therefore become important, in order to preserve the genetic heritage of rye. In this study, genetic diversity of rye landraces collected in a sector of the Italian Alps particularly suited to traditional agriculture was investigated using the ddRADseq technique. A few landraces still managed with family farming turned out to be genetically distant from the commercial varieties currently in use, highlighting that the phenomenon of homogenization of the local genetic pool can be still circumvented. Ex situ conservation of genetically divergent landraces is a valid tool to avoid the dissipation of an as yet unexplored genetic potential.
\end{abstract}

Keywords: crop genetic diversity; ddRAD sequencing; landrace; population structure; Secale cereale; Western Alps; rye

\section{Introduction}

Globally, there are approximately 382,000 species of vascular plants on the Earth [1] and more than 6000 have been cultivated for food production [2]. However, fewer than 200 species have significant productions globally, with only nine (sugar cane, maize, rice, wheat, potatoes, soybeans, oil-palm fruit, sugar beet, and cassava) accounting for over 66 percent of all crop production by weight [2]. Between the 200 most cultivated crops we can individuate several thousands of varieties and landraces. A landrace is a domesticated, locally adapted, traditional variety that has developed over time, through adaptation to its natural and cultural environment, and due to isolation from other populations of the species [3,4].

Even if the genetic diversity within a crop can be broad, genetic erosion due to loss of variation and genetic vulnerability at the species level are growing matters of concern in several crops. In common rye (Secale cereale L.), as for other crops, the replacement of local landraces with modern varieties is one of the main reason for the loss of genetic variation.

Recent studies have shown that currently cultivated rye, especially modern cultivars, are genetically less diverse and differentiated than local landraces [5,6]. To obtain modern breeds, in fact, parental inbred lines are developed by recurrent selfing of parental 
plants $[7,8]$. In rye, narrowing of the genetic base impacts variation of different traits: variability for spring vs. winter habit, winter-hardiness, plant height, lodging resistance, disease resistance, seed color, straw stiffness, earliness, pathogen resistance, ploidy, and grain yield and quality $[9,10]$. The consequence is a decrease in selection gain and an increase in susceptibility to biotic and abiotic stresses, coupled with the threat of further genetic erosion [11].

According to a 2020 world survey genetic resources of rye include 26,100 seed accessions encompassing most of the species in the genus Secale, but which are much less than in wheat (555,449 accessions) and barley (339,563 accessions) [12]. Rye ex situ collections are lower than other cereals also because most of the species in the genus Secale are open pollinated and therefore much more difficult to maintain via regeneration of seed accessions.

Landraces are genetically heterogeneous populations generated in subsistence agriculture and, in this regard, they share with wild rye ancestors much more variation than modern varieties [12]. Thanks to the maintenance in situ by farmers, landraces are regarded as key components of plant biodiversity in world agro-systems, also under a cultural and social perspective. While before the 30 s of the twentieth century, each mountain community cultivated its own crops, currently cultivated rye belongs to few commercial varieties [4]. During the "green revolution" in the 60s, many of these cultivars were abandoned for the more productive commercial varieties. Annual agricultural production benefited from this revolution at the expense of crop biodiversity and genetic variability [6,11]. These phenomena are more severe on mountains where depopulation forced a substantial change of patterns in the agro-pastoral land use at high-elevations. These coupled phenomena strongly reduced the number of already available local rye varieties (or landraces) [13].

In recent years, several initiatives have started to re-evaluate the importance of crop local varieties and to preserve their diversity by ex-situ and on-farm conservation, also in the perspective of feeding 50 billion people in 2050 [14]. Rye landraces have very rich and complex ancestry holding variation in response to many diverse stresses (low temperatures, drought, and low soil fertility) and are useful resources for the development of future crops deriving many sustainable traits from their heritage [15].

In Europe, for its use as food, feed and energy in biogas plants, rye is widely cultivated in Eastern, Central and Northern Europe, particularly in Poland, Germany, Ukraine and Russia. Even if subject to the ergot disease (Claviceps purpurea (Fr.) Tul.), rye presents several disease resistance genes reducing the need for phytochemicals [16,17]. Moreover, rye offers many traits for improved nutrition in cereals, particularly a high level of dietary fiber and a whole suite of minerals $(\mathrm{Zn}, \mathrm{Fe}, \mathrm{P})$, arabinoxylans, beta-glucans, resistant starch, and bioactive compounds [10,18], with positive effects on human health [19]. Grain content of antioxidants, phenolics, and dietary fibers in rye landraces are presently under study (M. Blandino pers. comm.).

Recently, a complete genome of rye was assembled [20]; nevertheless, know-how on rye genetics still remains marginal, when compared to other important crops and cereals [21]. Several studies on relationships within [22-24] and between Secale species [25-27] have been carried out to study the genetic variability, using a variety of different methods. The molecular tools employed in these analyses include PCR-RFLP [28], RAPD [22,23], ISSR [23], AFLP [29-31], SAMPL [23], DArT [5,32], isoenzymatic markers [22,24], SSR [6,23,25,33,34], and single nucleotide polymorphisms (SNP) [35].

In this study, ddRAD-seq has been applied to examine the genetic diversity and structure within different $S$. cereale landraces sampled in a mountain range spanning from the Ligurian (Cuneo Province) to Pennine Alps (Verbano-Cusio-Ossola Province) in NWItaly. In this area, rye was traditionally the most cultivated cereal for the production of flour [36,37] and of straw of good quality [38]. Less than one century ago, in Cuneo province alone, more than 28,000 ha were seeded with rye; now, the currently cultivated surface in whole Italy is 3580 ha (ISTAT 2020). By means of several interviews conducted among local populations, a few viable local rye varieties were tracked down. Landraces 
were also genetically compared with commercial ryes representative of EU market and with the perennial Secale strictum (Presl.) Presl. (syn. Secale montanum Guss.).

The aim of this study was to explore the genetic diversity in still-viable Italian NWAlps rye landraces, in order to understand which of them deserve conservation efforts, due to their "authentic" adaptation to local environmental conditions. The most promising candidates will be kept as repositories of potential genetic diversity.

\section{Results}

We obtained 482,236,822 demultiplexed sequences representing 30,835 polymorphic loci among 31,595 genotyped loci. Globally we recorded 173,451 polymorphic sites. After clone-correction and informative loci filtering we obtained 17,705 loci and 119,814 polymorphic sites.

AMOVA showed no genetic variation among samples within populations $(p>0.05)$. This is confirmed by the high differentiation $(\mathrm{Phi}=0.30 ; p<0.001$ ) between landraces/varieties. The overall variation within individuals is significant $(\mathrm{Phi}=0.24 ; p<0.001)$, revealing the presence of distinctive samples significantly divergent from the other individuals, and thus the presence of an inner genetic structure (Table 1).

Table 1. AMOVA results. Sigma values representing the variance, $\sigma$, for each landraces/varieties (populations) and the percent of the total variance explained by each source of variance. Phi $(\phi)$ provides the landraces/varieties differentiation statistics. Higher Phi value corresponds to higher amount of differentiation. $p$-values refers to a two-tailed F-test.

\begin{tabular}{ccccc}
\hline Components of Covariance & Sigma & $\mathbf{\%}$ & Phi & $\boldsymbol{p}$-Value \\
\hline Variance between populations (landraces/varieties) & 170.5 & 29.8 & 0.30 & $<0.001$ \\
Variance between individuals within landraces/varieties & -31.7 & -5.5 & 0.00 & $>0.05$ \\
Variance within individuals & 432.7 & 75.7 & 0.24 & $<0.001$ \\
Total variations & 571.5 & 100 & & \\
\hline
\end{tabular}

Pairwise comparison of mean genetic distances between populations and species calculated by means of Fst statistics are reported in Figure 1. The heatmap of Figure 1a reports pairwise comparisons on the whole genetic dataset and shows that Secale strictum is genetically distinguished from all the remaining rye populations (mean Fst $>0.55$ ); nevertheless, a group of four landraces grouped together at an intermediate distance between S. strictum samples and all the other landraces and varieties (Figure 1a; ARN, MIN, EST and SUN, see also the comment of Figure 1b). When pairwise comparisons were conducted only on S. cereale accessions, thus excluding S. strictum samples, we observed no other clear structures (Figure 1b). However, ARN, EST, and MIN landraces, now, showed significant moderate genetic distances from remaining rye accessions and high to very high genetic separation from the commercial hybrid Su Nasri (SUN) (Figure 1b). Moreover, ARN and MIN are genetically closer to EST and MAR than to any other accession. Very low genetic distances were registered between landrace pairs CAR and PEV, ROB and GAR, and DID and BRU, other than between the commercial open pollinated variety Antoninskie (ANT) and FRA.

Parameters of genetic diversity for rye accessions are presented in Table 2. The observed heterozygosity (Ho) ranged from 0.0281 (EST) to 0.0018 (GAR) and expected heterozygosity (He) from 0.00315 (EST) to 0.00185 (CAR), with an average of 0.00215 and 0.00218 , respectively. In Table 2 , rye accessions possessing negative $F$ values, which corresponds to observed heterozygosity values greater than expected according to the Hardy-Weinberg equilibrium, are shaded in grey. F (inbreeding coefficient) ranged from 0.1079 (EST) to -0.2593 in SUN (the hybrid variety) with an average value of 0.003 accounting for a very low level of inbreeding and a high proportion of heterozygous individuals in almost all rye accessions. The nucleotide diversity $(\pi)$ ranged from 0.00333 (EST) to 0.00146 (MUS) with an average of 0.00231 at the population level, and with no significant differences in absolute values with the two modern varieties. 


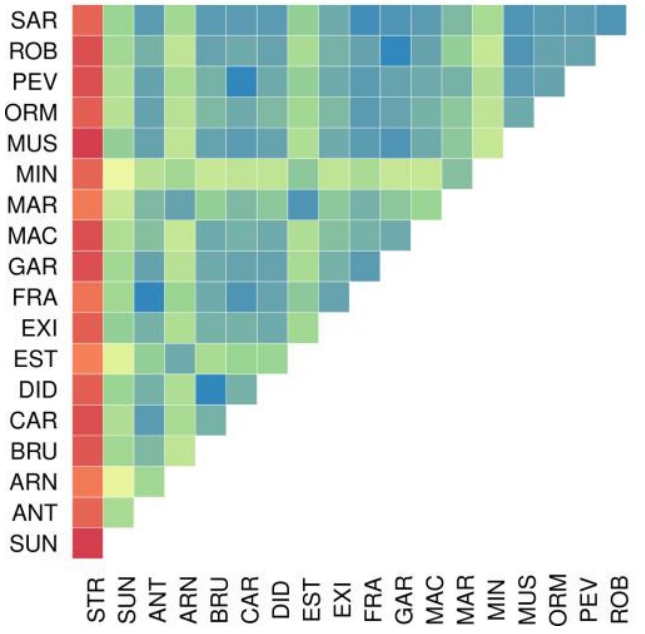

(a)

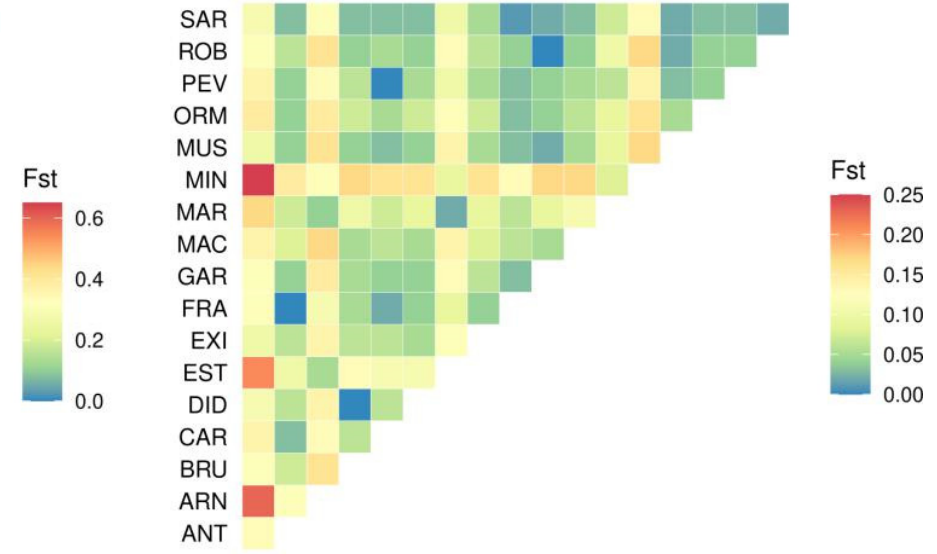

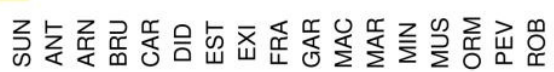

(b)

Figure 1. Pairwise genetic distances (Fst) between accessions. In both the two heat-maps, genetic distance is: Low distance $0.00<x<0.05$ (in blue-green), Moderate distance $0.05<x<0.15$ (in yellow-orange) and High to Very High distance $0.15<\mathrm{x} \leq 0.25$ (in dark orange-red). (a) Genetic distances are calculated for all the 19 accessions; (b) genetic distances are calculated after omitting STR (S. strictum).

Table 2. Estimates of genetic diversity per population. Observed $\left(\mathrm{H}_{\mathrm{O}}\right)$ and expected heterozygosity $\left(\mathrm{H}_{\mathrm{e}}\right)$ describe the proportion of heterozygous genotypes expected under the Hardy-Weinberg equilibrium [39] and the actual observed proportion of heterozygosity among samples (individuals) belonging to a population. F (inbreeding coefficient) is used to measure the inbreeding index in the population. Nucleotide diversity $(\pi)$ is used to measure the degree of polymorphism within a population [40]. Accessions are ordered according to decreasing F values. Average values and standard deviation (SD) are reported at the bottom of the table for each genetic parameter.

\begin{tabular}{ccccc}
\hline Accession & $\mathbf{H}_{\mathbf{o}}$ & $\mathbf{H}_{\mathbf{e}}$ & $\mathbf{F}$ & $\boldsymbol{\pi}$ \\
\hline EST & 0.00281 & 0.00315 & 0.1079 & 0.00333 \\
EXI & 0.00197 & 0.00218 & 0.0963 & 0.00231 \\
MAR & 0.00206 & 0.00226 & 0.0885 & 0.00238 \\
SAR & 0.00235 & 0.00254 & 0.0748 & 0.00269 \\
FRA & 0.00236 & 0.00253 & 0.0672 & 0.00268 \\
ANT & 0.00205 & 0.00217 & 0.0553 & 0.0023 \\
ROB & 0.00193 & 0.00204 & 0.0539 & 0.00216 \\
ORM & 0.00204 & 0.00214 & 0.0467 & 0.00227 \\
MAC & 0.00232 & 0.00243 & 0.0453 & 0.00257 \\
BRU & 0.00238 & 0.00249 & 0.0442 & 0.00263 \\
ARN & 0.00192 & 0.002 & 0.04 & 0.00211 \\
GAR & 0.0018 & 0.00186 & 0.0323 & 0.00197 \\
DID & 0.00233 & 0.00232 & -0.0043 & 0.00246 \\
STR & 0.00196 & 0.00192 & -0.0208 & 0.00203 \\
MIN & 0.00241 & 0.00236 & -0.0212 & 0.00249 \\
MUS & 0.00143 & 0.00138 & -0.0362 & 0.00146 \\
CAR & 0.00214 & 0.00185 & -0.1568 & 0.00196 \\
PEV & 0.00225 & 0.00194 & -0.1598 & 0.00206 \\
SUN & 0.00238 & 0.00189 & -0.2593 & 0.00199 \\
\hline Average & 0.00215 & 0.00218 & 0.03 & 0.00231 \\
SD & 0.00025 & 0.00029 & 0.04 & 0.00031 \\
\hline
\end{tabular}

Analysis of the genetic structure revealed the existence of three major genetic groups within the Alpine landraces (modal $\Delta \mathrm{K}=3$ ) (Figures 2 and S1; Table S1). The larger group (cluster I) contained most of the rye landraces and the two modern varieties, SUN and ANT; the four landraces ARN, EST, MIN, and MAR grouped apart (cluster II) (Figure S1). 


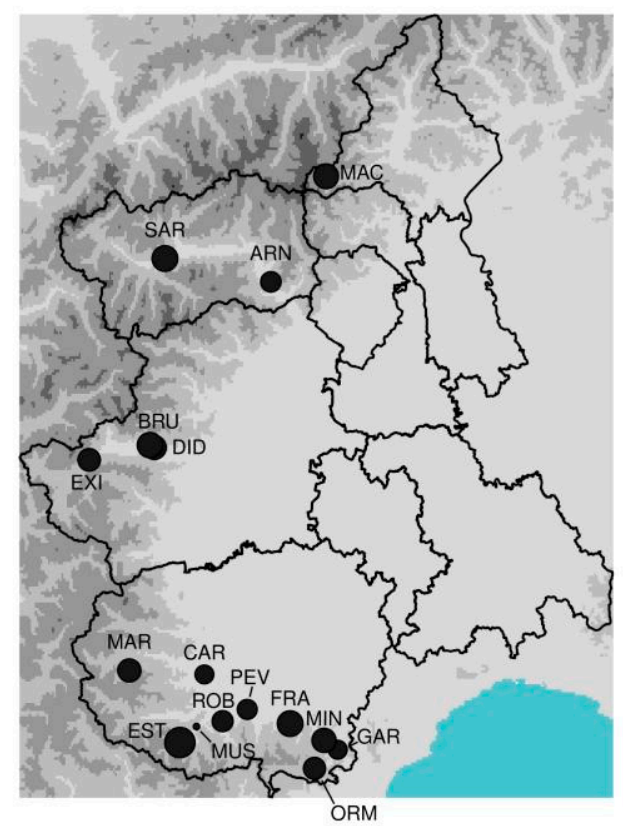

(a)

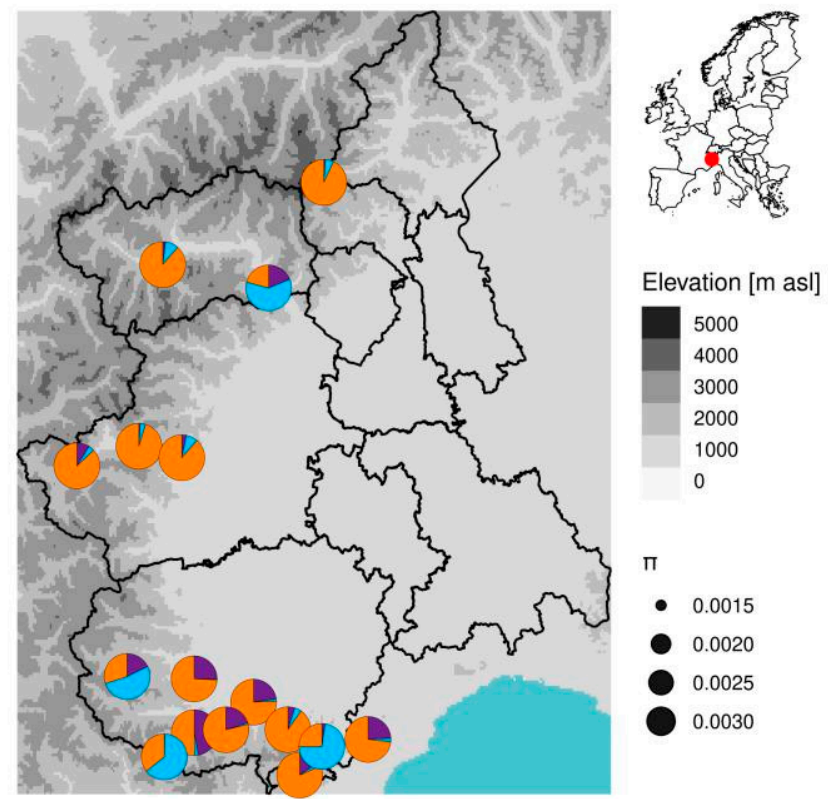

(b)

Figure 2. Geographic position of the rye landraces together with their nucleotide diversity and genetic structure. Each landrace is represented in the locality of collection along Western Alps. (a) Dot size corresponds to the mean nucleotide diversity. (b) Pie charts slices represent individuals probability to belong to one of the three genetic clusters calculated with STRUCTURE. Population IDs reported in (a) correspond to the populations in (b).

Estimated nucleotide diversity values $(\pi)$ between populations rounded around the average value of 0.00231 ( $\pm 0.00031 \mathrm{SD}$ ) (Figure S2). We observed two major deviations: the EST population with the bigger $\pi$ of 0.00333 and the smaller value of 0.00146 for the MUS population. All the other populations own a similar nucleotide diversity; otherwise, results pointed out that generally populations of the cluster II (ARN, MAR, MIN, and EST) show values greater than commercial varieties SUN and ANT (Table 2; Figure 2a).

Results of the DAPC analysis helped to better understand genetic relationships between varieties and alpine landraces included in the large group of rye accessions (group I in Figure S1; Figure 3). The optimal number of principal components was 80, and we performed the analysis using 13 discriminant factors (nPop-1), as suggested by Jombart [41]. The multivariate analysis revealed how most landraces are tightly related to ANT, the commercial variety of rye, while the commercial hybrid Su Nasri (SUN) was relatively isolated. Nonetheless, some landraces were positioned relatively distant from ANT, such as DID and BRU (from the Cottian Alps in Turin Province), or MAC and ORM, which, on the contrary, share no clear relationships and are placed at the northernmost and southernmost position of the geographic distribution, respectively (Figure 2a).

When we further inspected relationships within this group of accessions by means of their Prevosti's genetic distances (Figure S3), alpine landraces clustered coherently with results of the DAPC analysis, with the exception of the ORM landrace which was included in the main cluster with ANT. Setting the 0.02 genetic distance threshold among the ANT node, a big part of the rye landraces falls into the "ANT-like group", revealing a larger genetic similarity within these landraces and the variety Antoninskie (ANT). Considering that all these populations were part of the K2 genetic cluster, MAC, DID, and BRU can be regarded as only marginally related to ANT. Moreover, landraces DID and BRU can be considered as a single genetic unit, and the same can be said for the pairs PEV-CAR, GAR-ROB-(MUS), and FRA-ANT (see also pairwise genetic distances in Figure 1b). 


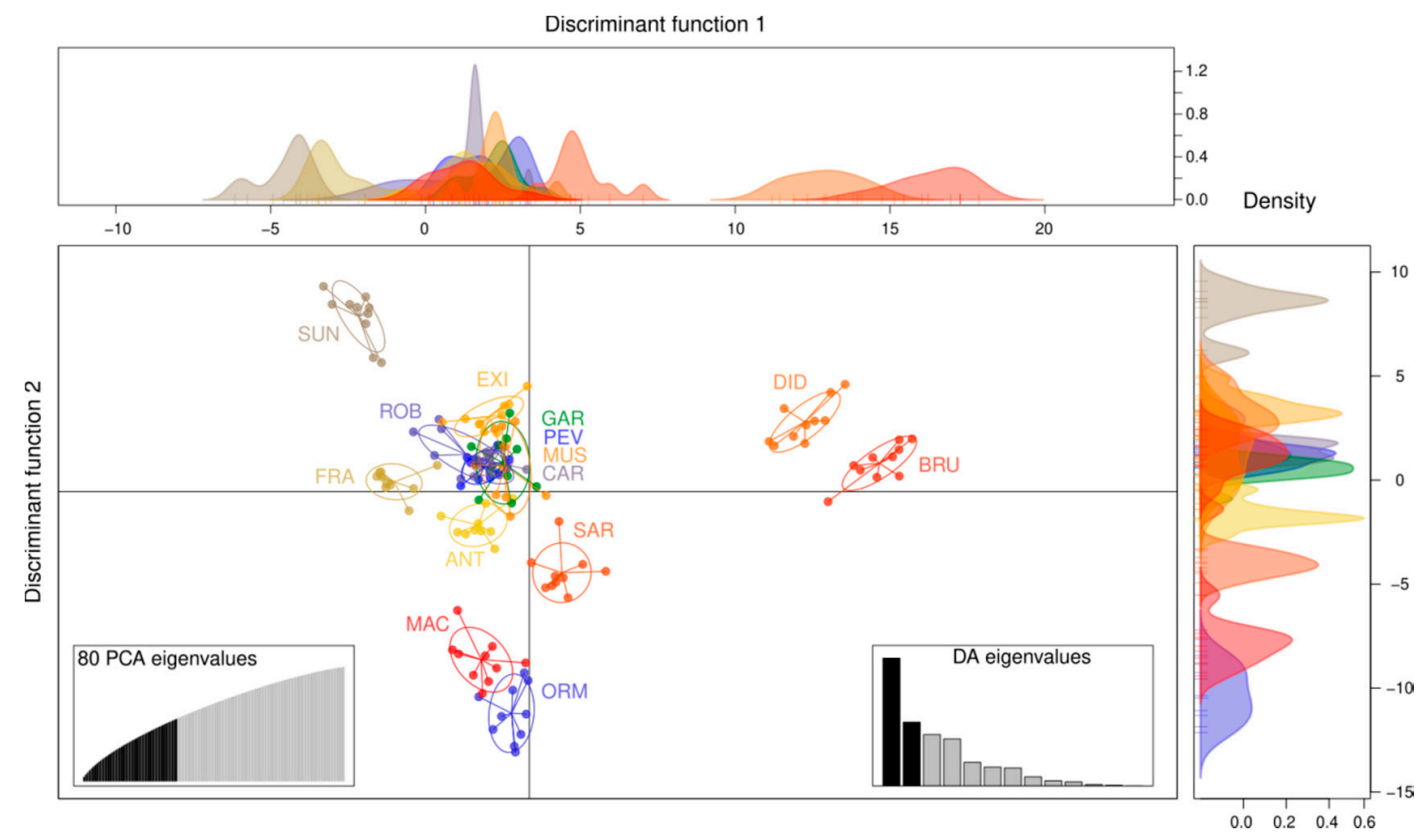

Figure 3. Relations between alpine landraces and modern varieties with a DAPC analysis. The multivariate analysis is based on 80 PCs. The majority of the landraces is related to Antoninskie (ANT). Density graphs (on the top and at the right of the DAPC representation) should help to interpret genetic distances between and within landraces and commercial varieties (ANT and SUN), and density corresponds to the genetic similarity within a single population.

The contribution of each genetic locus employed to analyse genetic distances and differentiation between populations of the alpine landraces was different according to the explained variance in the DAPC multivariate analysis. The most informative loci determining genetic distances among the two clusters of landraces were 39; we manually inspected their functional annotation after a blast and eight of them resulted in known plant functions (Table 3).

Table 3. Most informative loci. Best blast results for the most informative loci describing genetic distance between populations (DAPC-based).

\begin{tabular}{|c|c|c|c|c|c|c|}
\hline Locus ID & Description & E Value & $\operatorname{Id} \%$ & Accession & Putative Function & Reference \\
\hline 11747 & $\begin{array}{l}\text { Triticum aestivum cultivar Norstar } \\
\text { CBFIVb-B9 gene, promoter region, } 5^{\prime} \\
\text { UTR, and partial cds }\end{array}$ & $2.00 e-11$ & $73.53 \%$ & EU562190.1 & Cold acclimation & [42] \\
\hline 186075 & $\begin{array}{l}\text { Triticum aestivum cultivar Chinese } \\
\text { Spring fructose-1,6-bisphosphate } \\
\text { aldolase } 19 \text { (FBA19) gene, } \\
\text { complete cds }\end{array}$ & $4.00 e 28$ & $93.41 \%$ & KY930464.1 & $\begin{array}{l}\text { Heat and cold } \\
\text { stresses response }\end{array}$ & [43] \\
\hline 185806 & $\begin{array}{l}\text { Triticum aestivum gamma gliadin-A1, } \\
\text { gamma gliadin-A3, gamma } \\
\text { gliadin-A4, and LMW-A2 genes, } \\
\text { complete cds }\end{array}$ & $3.00 e-24$ & $95.71 \%$ & MG560140.1 & Gluten protein & [44] \\
\hline 274554 & $\begin{array}{l}\text { Aegilops tauschii subsp. tauschii } \\
\text { protein FAR1-RELATED } \\
\text { SEQUENCE 9-like } \\
\text { (LOC109763998), mRNA }\end{array}$ & $5.00 e 92$ & $81.07 \%$ & XM_020322871.1 & $\begin{array}{l}\text { Plant development } \\
\text { regulation }\end{array}$ & [45] \\
\hline 499375 & $\begin{array}{c}\text { Aegilops tauschii clone BAC } \\
\text { HD95L20 cytosolic acetyl-CoA } \\
\text { carboxylase (Acc-2) and putative } \\
\text { amino acid permeases genes, } \\
\text { complete cds }\end{array}$ & $6 e-43$ & $91.18 \%$ & EU660891.1 & $\begin{array}{l}\text { Flow of photosynth. } \\
\mathrm{C} \text { to metabolites }\end{array}$ & [46] \\
\hline
\end{tabular}


Table 3. Cont.

\begin{tabular}{|c|c|c|c|c|c|c|}
\hline Locus ID & Description & E Value & $\operatorname{Id} \%$ & Accession & Putative Function & Reference \\
\hline 186075 & $\begin{array}{l}\text { Aegilops tauschii chromosome 1Ds } \\
\text { prolamin gene locus, } \\
\text { complete sequence }\end{array}$ & $8 e-28$ & $93.41 \%$ & KY930464.1 & $\begin{array}{l}\text { Prolamine } \\
\text { synthesis }\end{array}$ & [47] \\
\hline 255304 & $\begin{array}{l}\text { Triticum turgidum HMW-glutenin } \\
\text { locus, complete sequence }\end{array}$ & $1 e-93$ & $90.33 \%$ & AY368673.1 & Gluten protein & [47] \\
\hline 276443 & $\begin{array}{c}\text { Hordeum vulgare subsp. vulgare } \\
\text { cultivar Nure frost resistance H2 gene } \\
\text { locus, complete sequence }\end{array}$ & $6 e 24$ & $93.88 \%$ & MN251600.1 & Frost resistance & [48] \\
\hline
\end{tabular}

\section{Discussion}

Genetic diversity of rye landraces was investigated in seed accessions derived from living populations sampled along the Italian Western Alps. We used an original approach for rye, ddRAD sequencing, which allowed us to sample genetic diversity for a large territory, where rye has been the crop key to the local economy (i.e., the Occitan Valleys of Piedmont) and an important source of livelihood, and nowadays, it has become a relict crop [36,38], historically funded on the cultivation of this ancient crop [37,49].

Seed accessions were obtained from local farmers, institutions (EAPAM) and from two seed banks (IPK and IAR). Landraces were genetically compared with two commercial ryes, largely marketed throughout Europe. The ddRAD sequencing allowed the analysis of 17,705 loci, an unprecedented deep analysis in rye, where several recent studies do not exceed the hundreds of loci analyzed $[5,12,35]$.

\subsection{Genetic Diversity}

Traditional rye varieties are panmictic populations, characterized by high levels of heterozygosity and heterogeneity (seven in Bolibok-Bragoszewska et al. [5]). Previous observations conducted on SNP polymorphisms of wild, feral, and cultivated rye sampled in different parts of the globe had shown very small differences in total genetic diversity among geographical populations [35]. Conversely, in our study, the AMOVA showed that the majority of genetic diversity was present between populations (landraces and varieties) of the alpine rye, and individuals were globally significantly diverse among them. Moreover, our AMOVA showed very little genetic diversity between individuals of single populations, and their differentiation was not significant.

Hangenlad et al. [35] have explained the low differentiation found between Eurasian rye landraces as a consequence of the very low level of inbreeding (low F values), as expected by an outcrossing species. In a consistent group of landraces of our study, F values were significantly higher than in the work of Hangenlad et al. [35]. In 11 out of 16 alpine landraces, F values were positive and ranged from 0.03 to 0.10 , thus indicating that the frequency of observed heterozygosity was lower than the Hardy-Weinberg expectation. In three landraces (MAR, EXI and EST), particularly, inbreeding coefficients exceeded 0.09, which is largely higher than mean $\mathrm{F}$ values found in literature (Hangenlad's landraces; $\mathrm{F}=-0.116$ ). In the case of the EST, an F value of 0.108 can be regarded as a serious indication of inbreeding. EST comes from a local farmer which cultivates rye seeds inherited by its father and no other farmers grow rye in the surroundings; this is also the case of MAR $(F=0.089$; Table 2); F values are probably the result of self-pollination, repeated year by year.

Self-incompatibility in rye is not strict and, with the exception of early landraces and ancestors, mutations at two multiallelic loci, $\mathrm{S}$ and $\mathrm{Z}$, mapped on chromosomes $1 \mathrm{R}$ and $2 \mathrm{R}$, respectively, has led to self-fertility in the modern species. It has been proposed that selffertility mutations have been captured in current hybrid ryes during breeding programs after introgression of a dominant self-fertility gene [50] from Iranian and Argentinean germplasms (Bolibok-Bragoszewska et al. [5] and references therein). 
In DID, STR, MIN, MUS, CAR, PEV, and SUN, conversely, F values were negative, pointing to a condition of excess of observed heterozygosity. For SUN, this result was expected in consideration of its breeding history; current hybrids were obtained starting from genetically divergent inbreeds. In open-pollinated populations, experiencing a reduction of the effective size, an heterozygosis excess occurs, i.e., recently bottlenecked populations [51].

Under different circumstances, this can be the case in some of our rye accessions. For example, DID is repeatedly propagated at IPK to renew the ex situ accession, probably starting from a small number of seeds. In MIN, which is employed for the production of straw for packsaddles and only marginally for the grains, a condition of heterozygosity exceeding what is expected in a population at mutation drift equilibrium has most probably occurred.

Breeding lines in rye are thought to be exposed to severe inbreeding depression when repetitively self-fertilized due to the high load of recessive deleterious mutations accumulated in highly heterozygous species [52]. This seems not to be the case of CAR and PEV, which showed the lowest levels of inbreeding $(\mathrm{F}$ values $=-0.259)$ among the alpine landraces.

Surprisingly, EST counterpoised the highest F value with the highest nucleotide diversity $(\pi)$ recorded between accessions (Table 2, Figure 2a), meaning that even if a consistent proportion of alleles are homozygous, this landrace hosts a high number of SNPs in its genome. In this case, the $\pi$ is definitely above the average, but for the other landraces affected by high $\mathrm{F}$ values we cannot report the same finding, revealing the presence of critical situations for conservation.

We included in our analysis an Italian accession of S. strictum Presl., which grows in southern Italy as a feral plant [53] and that could have potentially hybridized with several rye landraces $[35,54]$. S. strictum together with $S$. vavilovii are in fact wild ryes related to the cultivated winter rye. However, while many authors have questioned the validity of S. vavilovii as a separate species [55], others formulated the hypothesis that cultivated rye evolved from S. strictum [5]. The latter was chosen in this study because, differently from $S$. vavilovii, it occurs throughout the Mediterranean Basin $[35,56]$ in perennial, open-pollinated populations [5] and it has been used in the past to create perennial rye hybrids [27]. However, the results of our study (Figure 1) have excluded recent hybridization phenomena of alpine landraces and varieties with this congeneric.

\subsection{Genetic Structure}

The structure of alpine rye populations turned out to be composed of three main genotypes, as observed in previous analyses using microsatellites and SNP array over a very large number of accessions [5], and of two main groups (cluster I and cluster II) (Figures $2 \mathrm{~b}$ and S1), similarly to the results of Targońska et al. [6]. We did not observe a clear geographic pattern in genetic structure among the observed landraces. At the local scale, it is difficult to retrace the presence of specific patterns, due the complex history of migrations and the intense commercial exchanges (Figure 2).

Since the two commercial varieties were included in cluster I, we further inspected the genetic structure of this group (DAPC and Prevosti's distances; Figures 3 and S2). Results revealed that many alpine landraces are tightly correlated with the commercial variety Antoninskie (ANT); for several of these landraces we can affirm that genetic distance between them and ANT was very small and probably they should be interpreted as a homogeneous genetic group (Figure S2).

The present study was conducted to identify valuable landraces from a sector of the Western Alps where the high rates of depopulation have involved a general abandoning of agriculture with the risk of strong crop genetic erosion. We found two genetic clusters that could represent two main lineages of ryes. Unfortunately, our data do not allow the full interpretation by an historical point of view, but considering the tight relation between cluster I with modern rye varieties, we can hypothesize that cluster II composed of MAR, 
MIN, ARN, and EST should consist of "ancestral" rye landraces which were grown in Alpine valleys since before the 50s of the twentieth century. This hypothesis is supported by high $\pi$ values which characterized EST (0.003) together with MIN and MAR (where $\pi$ is higher than the average value 0.00231 ), where genetic diversities are typical of many "traditional" landraces [12,57].

Divergent landraces of cluster II are similarly managed with family farming, despite coming from four rather distant sites. MIN was grown to be used as a filling for packsaddles and saddles. This rye has particularly short and thin stems. EST and MAR landraces showed high and thin stems, suitable for making thatched roofs, the traditional roofs from the SW-Alps villages. ARN comes from Arnad (Aosta Valley) in the NW-Alps, a peculiar area in the Italian landscape influenced by French culture, where thatched roofs were less common, but where rye stems were traditionally used for stable and barn roofs. An AFLPs analysis conducted by IAR and the University of Torino [58] on rye varieties from Aosta Valley, highlighted the presence of two main genetic clusters where ARN belonged to a genetic cluster characterized by distinctive morphological features such as precocity, green spikes, long and thin stems, small seeds and a global lower productivity. These features were found by us also in three landraces (data not shown; see Figure S3); our hypothesis is that the $\mathrm{K} 1$ cluster is composed of ryes which were principally selected as raw materials for buildings and artifacts, i.e., thatched roofs or in other manufactures [36-38].

Genetic distances between cluster I and cluster II were found to be well statistically explained by 39 loci, and eight of them were functionally assigned in previous studies (Table 4). Given the limits of this analysis, it is interesting that all genes at the most informative loci, were involved in pathways which characterize rye as a crop, such as: cold stress resistance, low amount of gluten proteins, major or minor ability to extend the stem, and so on. This is even more interesting if cluster I and cluster II are so different, as discussed above, and this aspect deserves further analysis with appropriate methods (i.e., QTL mapping and WGSs).

Table 4. Rye Accessions list. For each seed accession, accession code, species, geographic provenance, elevation of the crop, life form, a brief description of the rye accession and main uses of the grains are given. Years of cultivation at the locality of sampling as declared by the owner (when available).

\begin{tabular}{|c|c|c|c|c|c|c|c|}
\hline $\begin{array}{l}\text { Accession } \\
\text { ID }\end{array}$ & Species & $\begin{array}{l}\text { Geographic } \\
\text { Origin }\end{array}$ & Elevation $^{1}$ & Life Form & Description & Years & Uses \\
\hline STR & S. strictum & $\begin{array}{l}\text { Monti-Sibillini, } \\
\text { M. Rotondo, } \\
\text { MC }\end{array}$ & - & perennial & $\begin{array}{l}\text { Wild congeneric species } \\
\text { supplied by IPK [R 898] }\end{array}$ & - & N.A. \\
\hline SUN & S. cereale & N.A. & N.A. & annual & $\begin{array}{l}\text { "Su Nasri" commercial hybrid, } \\
\text { responsible of selection and } \\
\text { conservation: Saaten-Union } \\
\text { GmbH, Isernhagen Germany; } \\
\text { supplied by RV Venturoli, } \\
\text { Pianoro, Italy }\end{array}$ & - & $\begin{array}{l}\text { EU Market, for food, } \\
\text { feed and energy }\end{array}$ \\
\hline ANT & S. cereale & N.A. & N.A. & annual & $\begin{array}{l}\text { “Antoninskie" commercial } \\
\text { open pollinated variety } \\
\text { responsible of selection and } \\
\text { conservation: Poznańska } \\
\text { Hodowla Roślin Sp. z o.o., } \\
\text { Tulce, Poland; supplied by } \\
\text { Società Italiana Sementi, San } \\
\text { Lazzaro di Savena, Italy }\end{array}$ & - & $\begin{array}{l}\text { EU Market, for food, } \\
\text { feed and energy }\end{array}$ \\
\hline ARN & S. cereale & Arnad, AO & 361 & annual & $\begin{array}{l}\text { Landrace supplied by IPK } \\
\text { [R 1137] }\end{array}$ & - & N.A. \\
\hline BRU & S. cereale & Bruzolo, TO & 455 & N.A. & $\begin{array}{l}\text { Landrace supplied by IPK } \\
\text { [R 1138] }\end{array}$ & - & $\begin{array}{l}\text { Seed accession stored } \\
\text { ex situ }\end{array}$ \\
\hline CAR & S. cereale & Caraglio, CN & 566 & annual & Landrace & $8-10$ & $\begin{array}{l}\text { Own milling (French } \\
\text { millstone), flour } \\
\text { transformation and } \\
\text { bread production } \\
\text { for sale. }\end{array}$ \\
\hline
\end{tabular}


Table 4. Cont

\begin{tabular}{|c|c|c|c|c|c|c|c|}
\hline $\begin{array}{l}\text { Accession } \\
\text { ID }\end{array}$ & Species & $\begin{array}{c}\text { Geographic } \\
\text { Origin }\end{array}$ & Elevation $^{1}$ & Life Form & Description & Years & Uses \\
\hline DID & S. cereale & $\begin{array}{l}\text { San Didiero, } \\
\text { (Fraz. Costa } \\
\text { Pietra), TO }\end{array}$ & 430 & N.A. & $\begin{array}{l}\text { Landrace supplied by IPK } \\
\text { [R 1140] }\end{array}$ & - & $\begin{array}{l}\text { Seed accession stored } \\
\text { ex situ }\end{array}$ \\
\hline EST & S. cereale & Entracque, $\mathrm{CN}$ & 1150 & annual & Landrace supplied by EAPAM & - & N.A. \\
\hline EXI & S. cereale & $\begin{array}{c}\text { Exilles } \\
\text { (Locality Cels), } \\
\text { TO }\end{array}$ & 955 & annual & $\begin{array}{l}\text { Landrace, supplied by Molino } \\
\text { Valsusa in Bruzolo (TO) }\end{array}$ & - & $\begin{array}{l}\text { Own milling } \\
\text { (millstones), flour } \\
\text { and bread }\end{array}$ \\
\hline FRA & S. cereale & Frabosa, $\mathrm{CN}$ & 505 & annual & Landrace & 8 & $\begin{array}{l}\text { Own milling } \\
\text { (millstones), flour, } \\
\text { bread and biscuits for } \\
\text { the family-run } \\
\text { farm-house; bedding } \\
\text { straw, thatched roofs }\end{array}$ \\
\hline GAR & S. cereale & Garessio, CN & 620 & annual & Landrace & - & $\begin{array}{l}\text { Flour and bread for } \\
\text { the family-run } \\
\text { farm-house }\end{array}$ \\
\hline MAC & S. cereale & $\begin{array}{l}\text { Macugnaga, } \\
\text { VB }\end{array}$ & 1327 & annual & $\begin{array}{l}\text { Landrace supplied by IPK } \\
\text { [R 1136] }\end{array}$ & - & N.A. \\
\hline MAR & S. cereale & $\begin{array}{l}\text { Marmora } \\
\text { (Locality } \\
\text { Torello), CN }\end{array}$ & 1410 & annual & Landrace & 20 & $\begin{array}{l}\text { Own milling } \\
\text { (millstones) for a } \\
\text { family-run } \\
\text { farm-house } \\
\end{array}$ \\
\hline MIN & S. cereale & $\begin{array}{c}\text { Garessio } \\
\text { (Locality } \\
\text { Mindino), } \mathrm{CN}\end{array}$ & 1000 & annual & Landrace & - & $\begin{array}{c}\text { Packsaddle and } \\
\text { saddle straw } \\
\text { production by the } \\
\text { farmer }\end{array}$ \\
\hline MUS & S. cereale & $\begin{array}{l}\text { Sant'Anna di } \\
\text { Valdieri, CN }\end{array}$ & 1000 & annual & $\begin{array}{l}\text { Landrace, supplied by EAPAM, } \\
\text { Ecomuseo della segale }\end{array}$ & - & $\begin{array}{l}\text { A blend of grains } \\
\text { established at the } \\
\text { beginning of } 2000 \\
\text { from several local } \\
\text { landraces }\end{array}$ \\
\hline ORM & S. cereale & Ormea, CN & 1082 & annual & Landrace & 7 & $\begin{array}{l}\text { Flour and bread for } \\
\text { family use }\end{array}$ \\
\hline PEV & S. cereale & Peveragno, CN & 515 & annual & Landrace & 10 & $\begin{array}{c}\text { Flour sale for } \\
\text { catering }\end{array}$ \\
\hline ROB & S. cereale & Robilante, CN & 700 & annual & $\begin{array}{l}\text { Landrace supplied by M. } \\
\text { Giordano in Robilante (CN) }\end{array}$ & 40 & $\begin{array}{l}\text { Own milling } \\
\text { (millstones) for a } \\
\text { family use }\end{array}$ \\
\hline SAR & S. cereale & $\begin{array}{l}\text { Sarre-Bellon, } \\
\text { AO }\end{array}$ & 1400 & N.A. & Landrace supplied by IAR & - & $\begin{array}{l}\text { For family use } \\
\text { as flour }\end{array}$ \\
\hline
\end{tabular}

${ }^{1}$ meters above sea level; N.A. = Not Applicable; a dash was used to fill cells with unknown values.

No apparent geographic structure was found among the alpine landraces of this study; a lack of correspondence between genotypes and the place of origin in rye has been documented [5,28,31]. Rye pollen is wind-dispersed for long distances [59] and seed accessions could be exchanged or shared by different farmers for several different reasons (commerce, emigration, etc.). Only in the case of BRU and DID landraces (belonging to cluster I; Figure 2) were we able to hypothesize a clear geographic correspondence between these two landraces coming from Bruzolo and San Didiero, which are very close localities in Valle Susa (TO). Both landraces were obtained from seed accessions stored at the IPK where, as already discussed, repetitive regeneration cycles could have affected genetic diversity $[60,61]$. Moreover, genetically distant landraces are very rare at a single geographical site [12,62].

Uniformity of the genetic pool of cluster I could be interpreted as a form of genetic contamination induced by random cross-pollination between different crops or depending on the farmers which deliberately mixed the different seeds. Alternatively, these landraces have originated from a common modern variety as Antoninskie itself or a very similar commercial variety. 


\subsection{Final Considerations}

The presence of two clear genetic clusters within the W-Alps was likely to depend on the main local uses of these rye landraces; not only as foodstuffs, but also selected for roof building and the production of other manufacts. Landraces belonging to cluster II are rare, difficult to be obtained, and exposed to genetic erosion. The poor shelf life of rye seeds increases the vulnerability of this germplasm. On farm and ex situ preservation of the divergent landraces is encouraged, given their tendency to hybridize and the great wealth of genes they conceal.

It could be useful to remember that "authentic" local landraces are worthy of conservation, not only as part of a relict biodiversity, but also because landraces host genetic traits to respond to specific environmental stresses: traits which can be used in plant breeding and for the development of new resilient varieties.

As far as landraces of cluster I are concerned, a gene flow from commercial varieties towards them seems probable. Only four up to 16 landraces were completely separated, thus further investigation into their origin would be necessary. Morphological and agronomic analyses will clarify the relationship between some of these landraces and modern varieties. Most interesting landraces selected in this study are valuable under several agronomic aspects and they can be proposed in programs of crop enrichment and enforcement.

\section{Materials and Methods}

\subsection{Plant Material Samples Preparation}

In spring 2018, we started a survey to recover local rye varieties in NW-Italy. We recovered seeds of 10 rye varieties declared as "local" by the interviewed farmers. The Institut Agricole Régional (IAR) (Aosta, Italy), Ente Aree Protette Alpi Marittime (EAPAM) (Valdieri, Italy), and Liebniz Institute of Plant Genetics (IPK) (Leibniz, Germany) supplied seven landraces from Maritime, Graian, and Pennine Alps (Table 4, Figure 1). A commercial rye variety and a rye hybrid (ANT and SUN, respectively) widely cultivated in growing areas of North Europe and available also for the Italian market were used as controls. S. strictum seed accession was provided by IPK, supplying seeds from Italian Apennines, where the species grows wild.

Globally we analyzed 19 different seed accessions. Forty rye seeds (caryopsis) for each accession were sterilized for $60 \mathrm{~s}$ in $70 \%$ ethanol and then gently shaken twice in a sodium hypochlorite solution ( $10 \%$ commercial bleach in distilled water with $0.01 \%$ Tween 20 ) for $5 \mathrm{~min}$. Seeds were placed on wet sterile filter paper in petri dishes and incubated for two days at $4{ }^{\circ} \mathrm{C}$ and then moved to $24{ }^{\circ} \mathrm{C}$ with a $16 / 8 \mathrm{~h}$ light/dark cycle. After a few days (from one to seven), all mature seeds germinated. About $200 \mathrm{mg}$ of fresh material (the first two leaves) for each sample were freeze-dried and stored at $-20^{\circ} \mathrm{C}$. DNA extraction was performed with the NucleoSpin ${ }^{\circledR}$ Plant II from Macherey-Nagel (Düren, Germany) as described in the product manual, using the PW2 buffer protocol. Samples' quality was assessed by means of a NanoDrop ${ }^{\circledR}$ ND-1000 spectrophotometer from Thermo Scientific (Waltham, MA, USA) respecting the ranges $260 / 280 \geq 1.7$ and $1.8 \leq 260 / 230 \leq 2.2$. We quantified samples DNA concentration between 20 and $50 \mathrm{ng} / \mu \mathrm{L}$, using a Qubit ${ }^{\circledR} 2.0$ fluorometer by Invitrogen (Carlsbad, CA, USA) using the DNA BR Assay Kit. Samples were shipped to IGA Technology Services (Udine, Italy) to be prepared and sequenced for ddRAD sequencing.

\subsection{RADseq Genotyping}

ddRAD (double digest Restriction Associated DNA) libraries were produced following the IGATech (Udine, Italy) custom protocol, with minor modifications with respect to Peterson et al. [63]. Genomic DNA, fluorimetrically quantified, was normalized to concentration and double digested with SphI and EcoRI enzymes. Fragmented DNA was purified with Agencourt AMPureXP beads (Beckman Coulter, Brea, CA, USA) and ligated to barcoded adapters. Samples were pooled on multiplexing batches and bead purified. For each pool, targeted fragments distribution was collected on a BluePippin instrument 
(Sage Science Inc., Beverly, MA, USA). Gel eluted fraction was amplified with oligo primers that introduce TruSeq indexes (Illumina adapters) and subsequently bead purified. The resulting libraries are checked with both Qubit 2.0 fluorimeter (Invitrogen, Waltham, CA, USA) and Bioanalyzer DNA (Agilent technologies, Santa Clara, CA, USA). Libraries were processed with Illumina cBot for cluster generation on the flowcell, following the manufacturer's instructions and sequenced with V4 chemistry paired end $125 \mathrm{bp}$ mode on HiSeq2500 instrument (Illumina, San Diego, CA, USA).

\subsection{Data Analysis}

We analysed ddRAD-seq raw sequences using Stacks v2.0 [64] following the protocol described by Rochette and Cathchen [65]. We used the publicly available rye genome [66] to align RAD tags. We demultiplexed raw Illumina reads using the process_radtags utility included in Stacks v2.0. Sequences were aligned to the reference genome using BWAMEM [67] with default parameters and selecting of uniquely aligned reads (i.e., reads with a mapping quality $>4$ ). We detected all the covered loci from the aligned reads using the gstacks program and we filtered detected loci using the populations program in Stacks v2.0, which was ran with option $r=0.75$ in order to retain only loci that are represented in at least the $75 \%$ of the population.

The populations.structure file produced by the populations program was used as input file in the following analysis performed in the R v3.6.2 environment [68] with the package poppr v2.8.6 [69].

The following steps were done to compare rye varieties' genetic differentiation, excluding S. strictum samples (STR). We applied the clonecorrect function to identify duplicated multilocus genotypes into the original dataset and the informloci function to remove uninformative loci, setting the MAF threshold to 0.01. Expected and observed heterozygosity were calculated with the function poppr; the inbreeding index was calculated as $\mathrm{F}=\left(\mathrm{H}_{\mathrm{e}}-\mathrm{H}_{\mathrm{o}}\right) / \mathrm{H}_{\mathrm{e}}[39]$; and the nucleotide diversity $(\pi)$ was calculated from the population program in Stacks environment [40,70]. Analysis of Molecular Variance (AMOVA) [71] was performed to estimate molecular variance among and between samples and populations, using the poppr.amova function and the randtest.amova function to verify the covariance components (1000 permutations). We characterized each population with several indices for heterozygosity, evenness, and linkage with the poppr function. Bayesian clustering, implemented in STRUCTURE v2.3 [72], was used to infer the number of putative genetic clusters. We ran the final simulations with $1<\mathrm{K}<22$ and 30 iterations for each $\mathrm{K}$ value; each run comprised a burn-in period of $10^{5}$ iterations, followed by $10^{6}$ Markov chain Monte Carlo steps. Following Evanno et al. [73], we defined the most adequate value for the number of clusters $\mathrm{K}$ with the online tool STRUCTURE HARVESTER [74]. A DAPC analysis [41] was performed with the function dapc to visualize relative genetic distances between individuals. Most informative loci were extracted using the loadingplot function using a restrictive threshold of 0.05; sequences were identified by BLAST searches and collected from GenBank (http:/ / www.ncbi.nlm.nih.gov/genbank/, accessed on 10 August 2021), then functionally annotated for the locus function (when available).

We further inspected genetic distances within rye accessions calculating Prevosti's distances among populations [75] with the prevost.dist function and visualizing them with a neighbour joining tree (nj). We sampled tree topologies with a 1000 bootstrap and we considered as significant a minimum bootstrap value of 75 . We interpreted as varietyrelated landraces those falling under the rule "Calibration of threshold levels for molecular characteristics against the minimum distance in traditional characteristics" [76]; thus we applied the 0.02 genetic distance threshold as discriminant.

Supplementary Materials: The following are available online at https:/ / www.mdpi.com/article / 10.3390/plants10112415/s1, Table S1: Evanno method results, Figure S1: STRUCTURE output for $K=3$, Figure S2: Nucleotide diversity $(\pi)$ distribution among rye accessions, Figure S3: Neighbour joining tree based on Prevosti's genetic distances between accessions from cluster I. 
Author Contributions: Conceptualization, M.A., M.B., A.F., M.L. and M.M.; Methodology, M.A. and M.M.; Formal Analysis, M.A.; Investigation, M.A., M.L. and M.M.; Resources, M.M.; WritingOriginal Draft Preparation, M.A. and M.M., Writing—Review \& Editing, M.B., L.C., S.R.E. and M.L.; Supervision, M.B., M.L., M.M.; Project Administration, M.M.; Funding Acquisition, M.B., A.F., M.L. and M.M. All authors have read and agreed to the published version of the manuscript.

Funding: The present study was supported by Fondazione CRT within the project SECALP and by Fondazione CRC within the project SECNALP.

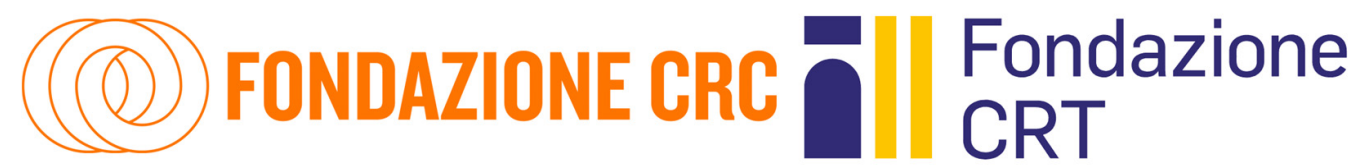

Data Availability Statement: The data presented in this study are openly available in NCBI-SRA, BioProject ID: PRJNA765145.

Acknowledgments: We thank Nanni Villani and Cati Caballo and the "Ecomuseo della Segale" at Ente Aree Protette Alpi Marittime (Valdieri, CN) for the support and information about local rye populations in the Cuneo province and for providing seeds of the landrace stored at the Ecomuseo. We thank Bruno Gallino and the Centro Regionale per la Biodiversità Vegetale "Emile Burnat" (CBV), for seed accessions conservation at Banca Regionale del Germoplasma. A special thank goes to Attilio Ianniello at Comizio Agrario (Mondovi, $\mathrm{CN}$ ) and to all the local farmers for collaborating to the study.

Conflicts of Interest: The authors declare no conflict of interest.

\section{References}

1. Mora, C.; Tittensor, D.P.; Adl, S.; Simpson, A.G.B.; Worm, B. How Many Species Are There on Earth and in the Ocean? PLoS Biol. 2011, 9, e1001127. [CrossRef] [PubMed]

2. FAO. The State of the World's Biodiversity for Food and Agriculture Fao Commission on Genetic Resources for Food and Agriculture Assessments; FAO: Rome, Italy, 2019; ISBN 9789251312704.

3. Villa, T.C.C.; Maxted, N.; Scholten, M.; Ford-Lloyd, B. Defining and identifying crop landraces. Plant Genet. Resour. 2005, 3, 373-384. [CrossRef]

4. Persson, K.; Von Bothmer, R. Genetic diversity amongst landraces of rye (Secale cereale L.) from northern Europe. Hereditas 2002, 136, 29-38. [CrossRef]

5. Bolibok-Bragoszewska, H.; Targońska, M.; Bolibok, L.; Kilian, A.; Rakoczy-Trojanowska, M. Genome-wide characterization of genetic diversity and population structure in Secale. BMC Plant Biol. 2014, 14, 184. [CrossRef] [PubMed]

6. Targońska, M.; Bolibok-Bragoszewska, H.; Rakoczy-Trojanowska, M. Assessment of Genetic Diversity in Secale cereale Based on SSR Markers. Plant Mol. Biol. Report. 2016, 34, 37-51. [CrossRef]

7. Feuillet, C.; Langridge, P.; Waugh, R. Cereal breeding takes a walk on the wild side. Trends Genet. 2008, 24, 24-32. [CrossRef] [PubMed]

8. Fisher, R.; McDowell, N.; Purves, D.; Moorcroft, P.; Sitch, S.; Cox, P.; Huntingford, C.; Meir, P.; Ian Woodward, F. Assessing uncertainties in a second-generation dynamic vegetation model caused by ecological scale limitations. New Phytol. 2010, 187, 666-681. [CrossRef] [PubMed]

9. Reitz, L.P.; Craddock, J.C. Diversity of Germ Plasm in Small Grain Cereals. Econ. Bot. 1969, 23, 315-323. [CrossRef]

10. Miedaner, T.; Hübner, M.; Korzun, V.; Schmiedchen, B.; Bauer, E.; Haseneyer, G.; Wilde, P.; Reif, J.C. Genetic architecture of complex agronomic traits examined in two testcross populations of rye (Secale cereale L.). BMC Genom. 2012, 13, 706. [CrossRef]

11. Smith, J.S.C.; Duvick, D.N.; Smith, O.S.; Cooper, M.; Feng, L. Changes in Pedigree Backgrounds of Pioneer Brand Maize Hybrids Widely Grown from 1930 to 1999. Crop Sci. 2004, 44, 1935-1946. [CrossRef]

12. Targonska-Karasek, M.; Boczkowska, M.; Podyma, W.; Pasnik, M.; Niedzielski, M.; Rucinska, A.; Nowak-Zyczynska, Z.; RakoczyTrojanowska, M. Investigation of obsolete diversity of rye (Secale cereale L.) using multiplexed SSR fingerprinting and evaluation of agronomic traits. J. Appl. Genet. 2020, 61, 513-529. [CrossRef] [PubMed]

13. Geiger, H.H.; Miedaner, T. Rye breeding. Cereals 2009, 3, 157-181.

14. United Nations General Assembly. Transforming Our World: The 2030 Agenda for Sustainable Development. Resolution Adopted by the UN General Assembly. 25 September 2015. Available online: https://sdgs.un.org/2030agenda (accessed on 8 September 2021).

15. Newton, A.C.; Akar, T.; Baresel, J.P.; Bebeli, P.J.; Bettencourt, E.; Bladenopoulos, K.V.; Czembor, J.H.; Fasoula, D.A.; Katsiotis, A.; Koutis, K.; et al. Cereal landraces for sustainable agriculture. A review. Agron. Sustain. Dev. 2010, 30, 237-269. [CrossRef]

16. Schlegel, R.; Melz, G. Genetic linkage map of rye (Secale cereale L.). Vor. Fuer Pflanz. 1996, 85, $33-45$. 
17. Korzun, V.; Malyshev, S.; Voylokov, A.V.; Börner, A. A genetic map of rye (Secale cereale L.) combining RFLP, isozyme, protein, microsatellite and gene loci. Theor. Appl. Genet. 2001, 102, 709-717. [CrossRef]

18. Andersson, R.; Fransson, G.; Tietjen, M.; Åman, P. Content and molecular-weight distribution of dietary fiber components in whole-grain rye flour and bread. J. Agric. Food Chem. 2009, 57, 2004-2008. [CrossRef]

19. Rosén, L.A.H.; Ostman, E.M.; Shewry, P.R.; Ward, J.L.; Andersson, A.A.M.; Piironen, V.; Lampi, A.-M.; Rakszegi, M.; Bedö, Z.; Bjorck, I.M.E. Postprandial glycemia, insulinemia, and satiety responses in healthy subjects after whole grain rye bread made from different rye varieties. 1. J. Agric. Food Chem. 2011, 59, 12139-12148. [CrossRef]

20. Rabanus-Wallace, M.T.; Hackauf, B.; Mascher, M.; Lux, T.; Wicker, T.; Gundlach, H.; Baez, M.; Houben, A.; Mayer, K.F.X.; Guo, L.; et al. Chromosome-scale genome assembly provides insights into rye biology, evolution and agronomic potential. Nat. Genet. 2021, 53, 564-573. [CrossRef]

21. Hayward, M.D.; Bosemark, N.O.; Romagosa, T. Plant Breeding: Principles and Prospects; Springer Science \& Business Media: Berlin/Heidelberg, Germany, 2012.

22. Matos, M.; Pinto-Carnide, O.; Benito, C. Phylogenetic relationships among Portuguese rye based on isozyme, RAPD and ISSR markers. Hereditas 2001, 134, 229-236. [CrossRef]

23. Bolibok, H.; Rakoczy-Trojanowska, M.; Hromada, A.; Pietrzykowski, R. Efficiency of different PCR-based marker systems in assessing genetic diversity among winter rye (Secale cereale L.) inbred lines. Euphytica 2005, 146, 109-116. [CrossRef]

24. Burger, J.C.; Lee, S.K.Y.; Ellstrand, N.C. Origin and genetic structure of feral rye in the western United States. Mol. Ecol. 2006, 15, 2527-2539. [CrossRef] [PubMed]

25. Shang, H.-Y.; Wei, Y.-M.; Wang, X.-R.; Zheng, Y.-L. Genetic diversity and phylogenetic relationships in the rye genus Secale L.(rye) based on Secale cereale microsatellite markers. Genet. Mol. Biol. 2006, 29, 685-691. [CrossRef]

26. Skuza, L.; Rogalska, S.M.; Bocianowski, J. RFLP analysis of mitochondrial DNA in the genus Secale. Acta Biol. Crac. Ser. Bot. 2007, 49, 77-87.

27. Gruner, P.; Miedaner, T. Perennial rye: Genetics of perenniality and limited fertility. Plants 2021, 10, 1210. [CrossRef]

28. Isik, Z.; Parmaksiz, I.; Çoruh, C.; Geylan-Su, Y.S.; Cebeci, O.; Beecher, B.; Budak, H. Organellar genome analysis of rye (Secale cereale) representing diverse geographic regions. Genome 2007, 50, 724-734. [CrossRef] [PubMed]

29. Salamini, F.; Özkan, H.; Brandolini, A.; Schäfer-Pregl, R.; Martin, W. Genetics and geography of wild cereal domestication in the near east. Nat. Rev. Genet. 2002, 3, 429-441. [CrossRef] [PubMed]

30. Chikmawati, T.; Skovmand, B.; Gustafson, J.P. Phylogenetic relationships among Secale species revealed by amplified fragment length polymorphisms. Genome 2005, 48, 792-801. [CrossRef]

31. Chikmawati, T.; Miftahudin, M.; Skovmand, B.; Gustafson, J.P. Amplified fragment length polymorphism-based genetic diversity among cultivated and weedy rye (Secale cereale L.) accessions. Genet. Resour. Crop Evol. 2012, 59, 1743-1752. [CrossRef]

32. Bolibok-Bragoszewska, H.; Heller-Uszyńska, K.; Wenzl, P.; Uszyński, G.; Kilian, A.; Rakoczy-Trojanowska, M. DArT markers for the rye genome-genetic diversity and mapping. BMC Genom. 2009, 10, 578. [CrossRef]

33. Fu, S.; Tang, Z.; Ren, Z.; Zhang, H.; Yan, B. Isolation of rye-specific DNA fragment and genetic diversity analysis of rye genus Secale L. using wheat SSR markers. J. Genet. 2010, 89, 489. [CrossRef]

34. Haseneyer, G.; Schmutzer, T.; Seidel, M.; Zhou, R.; Mascher, M.; Schön, C.C.; Taudien, S.; Scholz, U.; Stein, N.; Mayer, K.F.X.; et al. From RNA-seq to large-scale genotyping-genomics resources for rye (Secale cereale L.). BMC Plant Biol. 2011, 11, 131. [CrossRef] [PubMed]

35. Hagenblad, J.; Oliveira, H.R.; Forsberg, N.E.G.; Leino, M.W. Geographical distribution of genetic diversity in Secale landrace and wild accessions. BMC Plant Biol. 2016, 16, 23. [CrossRef] [PubMed]

36. Netting, R.M.; Netting, R.M. Balancing on an Alp: Ecological Change and Continuity in a Swiss Mountain Community; Cambridge University Press: Cambridge, UK, 1981.

37. Behre, K.E. The history of rye cultivation in Europe. Veg. Hist. Archaeobot. 1992, 1, 141-156. [CrossRef]

38. Laghetti, G.; Ghiglion, G.; Miceli, F.; Cifarelli, S.; Pignone, D.; Hammer, K. Collecting crop genetic resources in two Italian linguistic (Occitan and Ladin) islands and West Liguria with historical and ethnobotanical notes. Int. J. Biodivers. Conserv. 2012, 4 , 54-70. [CrossRef]

39. Nei, M.; Chesser, R.K. Estimation of fixation indices and gene diversities. Ann. Hum. Genet. 1983, 47, 253-259. [CrossRef] [PubMed]

40. Nei, M.; Jin, L. Variances of the average numbers of nucleotide substitutions within and between populations. Mol. Biol. Evol. 1989, 6, 290-300.

41. Jombart, T.; Devillard, S.; Balloux, F. Discriminant analysis of principal components: A new method for the analysis of genetically structured populations. BMC Genet. 2010, 11, 94. [CrossRef] [PubMed]

42. Badawi, M.; Danyluk, J.; Boucho, B.; Houde, M.; Sarhan, F. The CBF gene family in hexaploid wheat and its relationship to the phylogenetic complexity of cereal CBFs. Mol. Genet. Genomics 2007, 277, 533-554. [CrossRef]

43. Lv, G.Y.; Guo, X.G.; Xie, L.P.; Xie, C.G.; Zhang, X.H.; Yang, Y.; Xiao, L.; Tang, Y.Y.; Pan, X.L.; Guo, A.G.; et al. Molecular characterization, gene evolution, and expression analysis of the fructose-1, 6-bisphosphate Aldolase (FBA) gene family in wheat (Triticum aestivum L.). Front. Plant Sci. 2017, 8, 1030. [CrossRef]

44. Altenbach, S.B.; Chang, H.C.; Simon-Buss, A.; Mohr, T.; Huo, N.; Gu, Y.Q. Exploiting the reference genome sequence of hexaploid wheat: A proteomic study of flour proteins from the cultivar Chinese Spring. Funct. Integr. Genom. 2020, 20, 1-16. [CrossRef] 
45. Ma, L.; Li, G. FAR1-related sequence (FRS) and FRS-related factor (FRF) family proteins in arabidopsis growth and development. Front. Plant Sci. 2018, 9, 692. [CrossRef]

46. Podkowinski, J.; Jelenska, J.; Sirikhachornkit, A.; Zuther, E.; Haselkorn, R.; Gornicki, P. Expression of cytosolic and plastid acetyl-coenzyme A carboxylase genes in young wheat plants. Plant Physiol. 2003, 131, 763-772. [CrossRef]

47. Anderson, O.D.; Dong, L.; Huo, N.; Gu, Y.Q. A New Class of Wheat Gliadin Genes and Proteins. PLoS ONE 2012, 7, e52139. [CrossRef]

48. Pasquariello, M.; Barabaschi, D.; Himmelbach, A.; Steuernagel, B.; Ariyadasa, R.; Stein, N.; Gandolfi, F.; Tenedini, E.; Bernardis, I.; Tagliafico, E.; et al. The barley Frost resistance-H2 locus. Funct. Integr. Genom. 2014, 14, 85-100. [CrossRef]

49. Peratoner, G.; Seling, S.; Klotz, C.; Florian, C.; Figl, U.; Schmitt, A.O. Variation of agronomic and qualitative traits and local adaptation of mountain landraces of winter rye (Secale cereale L.) from Val Venosta/Vinschgau (South Tyrol). Genet. Resour. Crop Evol. 2016, 63, 261-273. [CrossRef]

50. Ralph, J.; Lundquist, K.; Brunow, G.; Lu, F.; Kim, H.; Schatz, P.F.; Marita, J.M.; Hatfield, R.D.; Ralph, S.A.; Christensen, J.H.; et al. Lignins: Natural polymers from oxidative coupling of 4-hydroxyphenyl-propanoids. Phytochem. Rev. 2004, 3, 29-60. [CrossRef]

51. Cornuet, J.M.; Luikart, G. Description and power analysis of two tests for detecting recent population bottlenecks from allele frequency data. Genetics 1996, 144, 2001-2014. [CrossRef] [PubMed]

52. Husband, B.C.; Schemske, D.W. Evolution of the magnitude and timing of inbreeding depression in plants. Evolution 1996, 50, 54-70. [CrossRef] [PubMed]

53. Pignatti, S.; Guarino, R.; La Rosa, M. Flora d'Italia, 2nd ed.; Edagricole: Bologna, Italy, 2017; ISBN 978-88-506-5242-6.

54. Jenabi, T.; Saeidi, H.; Rahiminejad, M.R. Biodiversity of Secale strictum in Iran measured using microsatellites. Genet. Resour. Crop Evol. 2011, 58, 497-505. [CrossRef]

55. Skuza, L.; Szućko, I.; Filip, E.; Strzała, T. Genetic diversity and relationship between cultivated, weedy and wild rye species as revealed by chloroplast and mitochondrial DNA non-coding regions analysis. PLoS ONE 2019, 14, e0213023. [CrossRef] [PubMed]

56. Sencer, H.A.; Hawkes, J.G. On the origin of cultivated rye. Biol. J. Linn. Soc. 1980, 13, 299-313. [CrossRef]

57. McCouch, S. Diversifying Selection in Plant Breeding. PLoS Biol. 2004, 2, e347. [CrossRef] [PubMed]

58. Portis, E.; Lanteri, S.; Bassignana, M.; Arlian, D.; Tarello, C.; Letey, M. Others Caratterizzazione e valorizzazione di ecotipi valdostani di segale. In Proceedings of the $8^{\circ}$ Convegno AISTEC “Evoluzione e Rilancio Della Filiera dei Cereali: Biodiversità, Sostenibilità, Tecnologie e Nutrizione", Aci Castello, Italy, 11-13 May 2011; p. 83.

59. Kozumplik, V.; Christie, B.R. Dissemination of orchard-grass pollen. Can. J. Plant Sci. 1972, 52, 997-1002. [CrossRef]

60. Chwedorzewska, K.J.; Bednarek, P.T.; Puchalski, J.; Krajewski, P. AFLP-profiling of long-term stored and regenerated rye Genebank samples. Cell. Mol. Biol. Lett. 2002, 7, 457-463.

61. Boczkowska, M.K.; Puchalski, J. SSR studies of genetic changes in relation to long-term storage and field regeneration of rye (Secale cereale) seeds. Seed Sci. Technol. 2012, 40, 63-72. [CrossRef]

62. Chebotar, S.; Röder, M.S.; Korzun, V.; Saal, B.; Weber, W.E.; Börner, A. Molecular studies on genetic integrity of open-pollinating species rye (Secale cereale L.) after long-term genebank maintenance. Theor. Appl. Genet. 2003, 107, 1469-1476. [CrossRef]

63. Peterson, B.K.; Weber, J.N.; Kay, E.H.; Fisher, H.S.; Hoekstra, H.E. Double digest RADseq: An inexpensive method for de novo SNP discovery and genotyping in model and non-model species. PLoS ONE 2012, 7, e37135. [CrossRef]

64. Catchen, J.; Bassham, S.; Wilson, T.; Currey, M.; O’Brien, C.; Yeates, Q.; Cresko, W.A. The population structure and recent colonization history of Oregon threespine stickleback determined using restriction-site associated DNA-sequencing. Mol. Ecol. 2013, 22, 2864-2883. [CrossRef]

65. Rochette, N.C.; Catchen, J.M. Deriving genotypes from RAD-seq short-read data using Stacks. Nat. Protoc. 2017, 12, 2640-2659. [CrossRef]

66. Bauer, E.; Schmutzer, T.; Barilar, I.; Mascher, M.; Gundlach, H.; Martis, M.M.; Twardziok, S.O.; Hackauf, B.; Gordillo, A.; Wilde, P.; et al. Towards a whole-genome sequence for rye (Secale cereale L.). Plant J. 2017, 89, 853-869. [CrossRef] [PubMed]

67. Li, H.; Durbin, R. Fast and accurate short read alignment with Burrows-Wheeler transform. Bioinformatics 2009, 25, 1754-1760. [CrossRef]

68. R Core Team. R: A Language and Environment for Statistical Computing; R Core Team: Vienna, Austria, 2019.

69. Kamvar, Z.N.; Tabima, J.F.; Grünwald, N.J. Poppr: An R package for genetic analysis of populations with clonal, partially clonal, and/or sexual reproduction. PeerJ 2014, 2014, e281. [CrossRef]

70. Catchen, J.M.; Amores, A.; Hohenlohe, P.; Cresko, W.; Postlethwait, J.H. Stacks: Building and genotyping Loci de novo from short-read sequences. G3 2011, 1, 171-182. [CrossRef] [PubMed]

71. Excoffier, L.; Smouse, P.E.; Quattro, J.M. Analysis of molecular variance inferred from metric distances among DNA haplotypes: Application to human mitochondrial DNA restriction data. Genetics 1992, 131, 479-491. [CrossRef]

72. Pritchard, J.K.; Stephens, M.; Donnelly, P. Inference of population structure using multilocus genotype data. Genetics 2000, 155, 945-959. [CrossRef]

73. Evanno, G.; Regnaut, S.; Goudet, J. Detecting the number of clusters of individuals using the software structure: A simulation study. Mol. Ecol. 2005, 14, 2611-2620. [CrossRef]

74. Earl, D.A.; VonHoldt, B.M. Structure harvester: A website and program for visualizing structure output and implementing the Evanno method. Conserv. Genet. Resour. 2012, 4, 359-361. [CrossRef] 
75. Prevosti, A.; Ocana, J.; Alonso, G. Distances between populations of Drosophila subobscura, based on chromosome arrangement frequencies. Theor. Appl. Genet. 1975, 45, 231-241. [CrossRef] [PubMed]

76. Achard, F.; Butruille, M.; Madjarac, S.; Nelson, P.T.; Duesing, J.; Laffont, J.; Nelson, B.; Xiong, J.; Mikel, M.A.; Smith, J.S.C. Single nucleotide polymorphisms facilitate distinctness-uniformity-stability testing of soybean cultivars for plant variety protection. Crop Sci. 2020, 60, 2280-2303. [CrossRef] 